\title{
Fabrication and photoluminescence of monolithic silica glass doped with alumina nanoparticles using $\mathrm{SiO}_{2}$-PVA nanocomposite
}

\author{
Hiroshi IKEDA, Takahiro MURATA* and Shigeru FUJINO ${ }^{\dagger}$ \\ Art, Science and Technology Center for Cooperative Research, Kyushu University, Kasuga, Fukuoka 816-8580, Japan \\ *Faculty of Education and Master's Course in Education, Kumamoto University, \\ 2-40-1 Kurokami, Chuo-ku, Kumamoto 860-8555, Japan
}

\begin{abstract}
$\mathrm{Al}_{2} \mathrm{O}_{3}$ nanoparticle doped $\mathrm{SiO}_{2}$-PVA nanocomposites were prepared using fumed silica, fumed alumina, and poly(vinyl alcohol) (PVA). Nanocomposites containing from 0 to $6 \mathrm{~mol} \% \mathrm{Al}_{2} \mathrm{O}_{3}$ were heat-treated in air at 1100 to $1300^{\circ} \mathrm{C}$ to obtain monolithic, transparent silica glass. The $0.6 \mathrm{~mol} \% \mathrm{Al}_{2} \mathrm{O}_{3}$ doped nanocomposite was sintered at $1200^{\circ} \mathrm{C}$, a higher temperature than was required for the non-doped nanocomposite. The obtained $\mathrm{Al}_{2} \mathrm{O}_{3}$ doped silica glass exhibited characteristic blue photoluminescence (PL) on UV excitation. The effects of the $\mathrm{Al}_{2} \mathrm{O}_{3}$ nanoparticles on the sintering temperature and the PL characteristics of the sintered silica glass are discussed in terms of the morphology and structure of the sintered glass.
\end{abstract}

(2015 The Ceramic Society of Japan. All rights reserved.

Key-words : Fumed silica, Fumed alumina, Composite, Silica glass, Sintering, Fluorescence

[Received December 26, 2014; Accepted April 16, 2015]

\section{Introduction}

Glasses doped with crystalline particles have received intense research interest owing to their outstanding properties, including transparency, good formability and unique optical and electrical characteristics. Among the various oxide glasses, silica glass is considered to be one of the most promising materials for matrix applications, because it exhibits high thermal stability and superior transparency in the vacuum-ultraviolet to near-infrared region of the spectrum. A sol-gel method has been used to fabricate silica glasses doped with various nanoparticles, and this technique allows controls over both the concentration and dispersion state of the dopants as a means of obtaining desirable properties in the glass. For instance, silica glasses doped with $\mathrm{SnO}_{2},{ }^{1)} \mathrm{TiO}_{2},{ }^{2)} \mathrm{ZnO}^{2)}$ or $\mathrm{Al}_{2} \mathrm{O}_{3}{ }^{3), 4)}$ have been prepared using the sol-gel method. Glasses doped with $\mathrm{Al}_{2} \mathrm{O}_{3}$ particles are of interest in the field of functional optical materials, because these show a strong photoluminescence (PL) band in the range of 400$600 \mathrm{~nm}$ upon UV excitation. ${ }^{3)}$ However, there have been no reports of monolithic silica glass doped with $\mathrm{Al}_{2} \mathrm{O}_{3}$ nanoparticles and so there is room for further investigation of the preparation process with respect to the fabrication of large and monolithic silica glass on the centimeter scale.

The fabrication of large and monolithic glasses has been performed using a particulate sol-gel process in which $\mathrm{SiO}_{2}$ particles are employed as the starting material. ${ }^{5)}$ In fact, silica glass rods, tubes and plates with sizes on the order of several tens of centimeters have been made by sintering $\mathrm{SiO}_{2}$ nanoparticles. ${ }^{6}$-10) Despite this, there have been few reports concerning the fabrication of monolithic silica glasses doped with crystalline nanoparticles using the conventional particulate sol-gel process. In previous work, monolithic silica glass doped with metal ions or

\footnotetext{
Corresponding author: S. Fujino; E-mail: fujino@astec.kyushu-u. ac.jp
}

nanoparticles was obtained using a newly developed fabrication process employing an $\mathrm{SiO}_{2}$-polyvinyl alcohol (PVA) nanocomposite as the silica glass precursor. ${ }^{11), 12)}$ The $\mathrm{SiO}_{2}$-PVA nanocomposite is prepared from fumed silica and PVA via an $\mathrm{SiO}_{2-}$ PVA suspension and is then sintered in air to fabricate a monolithic silica glass at the relatively low temperature of $1100^{\circ} \mathrm{C}$. In contrast, the conventional particulate sol-gel process requires sintering above $1300^{\circ} \mathrm{C}$ in an inert atmosphere. As previously reported, this lower sintering temperature allowed us to fabricate monolithic silica glass doped with various metal nanoparticles or rare-earth ions, including $\mathrm{Au}$ nanoparticles ${ }^{13)}$ and $\mathrm{Tb}$ ions. ${ }^{14)}$

In the present study, we further examined the preparation of monolithic silica glass doped with $\mathrm{Al}_{2} \mathrm{O}_{3}$ nanoparticles using the $\mathrm{SiO}_{2}$-PVA nanocomposite. The effects of $\mathrm{Al}_{2} \mathrm{O}_{3}$ nanoparticles addition on the sintering conditions and the PL characteristics of the glass are discussed in terms of the morphology and structure of the sintered glass. This paper reports the fabrication of transparent and monolithic silica glasses doped with $\mathrm{Al}_{2} \mathrm{O}_{3}$ nanoparticles and exhibiting PL characteristics.

\section{Experimental}

The preparation procedure of the $\mathrm{Al}_{2} \mathrm{O}_{3}$ nanoparticle doped

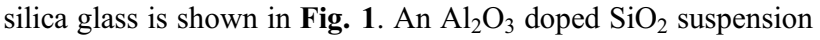
(8 wt. \%) was initially prepared from fumed silica (mean diameter of $7 \mathrm{~nm}$, Aerosil300, Nippon Aerosil, Japan) and fumed alumina $(\gamma$-alumina, mean diameter of $13 \mathrm{~nm}$, AluC, Nippon Aerosil, Japan) dispersed in water by ultra-sonication. The concentration of the $\mathrm{Al}_{2} \mathrm{O}_{3}$ in the $\mathrm{SiO}_{2}$ was varied from 0.02 to $6 \mathrm{~mol} \%$. An $8 \mathrm{wt}$ \% solution of PVA (degree of polymerization 1500-1800, degree of hydrolysis $78-82 \mathrm{~mol} \%$, Wako Pure Chemical, Japan) was prepared and added into the $\mathrm{Al}_{2} \mathrm{O}_{3}$ doped $\mathrm{SiO}_{2}$ suspension followed by mixing with a magnetic stirrer for $12 \mathrm{~h}$ at room temperature, resulted in the formation of a homogeneous suspension. The obtained suspension was poured into a container and subsequently dried at $30^{\circ} \mathrm{C}$ for one week under atmospheric 


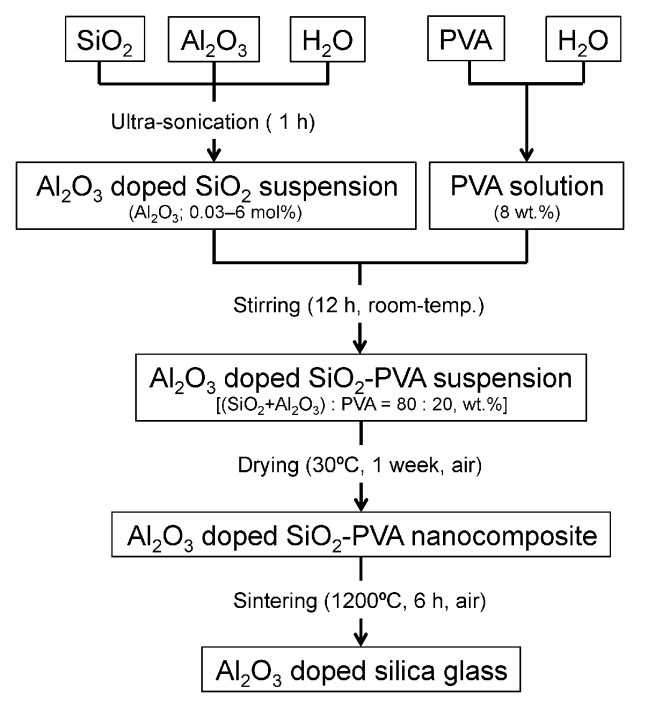

Fig. 1. Preparation procedure for the $\mathrm{Al}_{2} \mathrm{O}_{3}$ doped silica glass.

Table 1. Effects of temperature and holding time on the sintering behavior of $\mathrm{SiO}_{2}$-PVA nanocomposites doped with $0,0.6$ and $1.2 \mathrm{~mol} \%$ $\mathrm{Al}_{2} \mathrm{O}_{3}(\mathrm{O}=$ transparent, $\triangle$ = opaque, $\boldsymbol{\square}=$ crystalline. The symbols -, -- and --- indicate materials expected to be transparent, opaque and crystalline.)

\begin{tabular}{|c|c|c|c|c|c|c|c|c|}
\hline \multirow{2}{*}{$\begin{array}{c}\mathrm{Al}_{2} \mathrm{O}_{3} \text { amount } \\
(\mathrm{mol} \%)\end{array}$} & \multirow{2}{*}{$\begin{array}{c}\text { Temperature } \\
\left({ }^{\circ} \mathrm{C}\right)\end{array}$} & \multicolumn{7}{|c|}{ Holding time (h) } \\
\hline & & 0.5 & 3 & 6 & 8 & 9 & 12 & 18 \\
\hline 0 & 1100 & & $\bigcirc$ & $\bigcirc$ & - & - & $\bigcirc$ & $\bigcirc$ \\
\hline (Non-doped) & 1200 & & $\mathbf{\square}$ & $\mathbf{\square}$ & --- & $\mathbf{\square}$ & --- & --- \\
\hline \multirow{3}{*}{0.6} & 1100 & -- & -- & $\triangle$ & -- & -- & $\triangle$ & $\triangle$ \\
\hline & 1200 & -- & $\triangle$ & $\bigcirc$ & $\bigcirc$ & $\mathbf{\square}$ & $\mathbf{\square}$ & -- \\
\hline & 1300 & $\mathbf{\square}$ & --- & --- & --- & --- & --- & --- \\
\hline \multirow{2}{*}{1.2} & 1200 & -- & -- & $\triangle$ & $\triangle$ & $\mathbf{\square}$ & $\mathbf{\square}$ & -- \\
\hline & 1300 & $\mathbf{\square}$ & --- & --- & --- & --- & --- & --- \\
\hline
\end{tabular}

pressure. As the water in the sample evaporated during the drying process, the suspension gradually consolidated to form a wet gel, eventually generating a solid $\mathrm{Al}_{2} \mathrm{O}_{3}$ doped $\mathrm{SiO}_{2}$-PVA nanocomposite. The monolithic silica glass was finally obtained by sintering this nanocomposite at $1100-1300^{\circ} \mathrm{C}$ for various periods of time in air. The sintered samples were examined by X-ray diffraction (XRD; MultiFlex, Rigaku, Japan) and their morphologies were observed using transmission electron microscopy (TEM; JEM-1300NEF, JEOL, Japan) in conjunction with electron energy-loss spectroscopy (EELS). The PL characteristics of the sintered glasses were evaluated by means of a fluorescence spectrophotometer (F-4500, Hitachi, Japan) with a Xenon lamp source. The Vickers hardness (Hv) values of the samples were measured using a hardness testing apparatus (MVK-H1, Mitutoyo, Japan). The structure of each $\mathrm{Al}_{2} \mathrm{O}_{3}$ doped silica glass was analyzed with Fourier transform infrared spectroscopy (FT-IR; FTIR-8400, Shimadzu, Japan) applying the $\mathrm{KBr}$ pellet method.

\section{Results}

The amount of $\mathrm{Al}_{2} \mathrm{O}_{3}$ in the $\mathrm{SiO}_{2}$-PVA nanocomposite was found to affect the sintering temperature of the material. Table 1 summarizes the effects of temperature and hold time on the sintering process. In the case of the non-doped $\mathrm{SiO}_{2}$-PVA nanocomposite, transparent silica glass was obtained by sintering

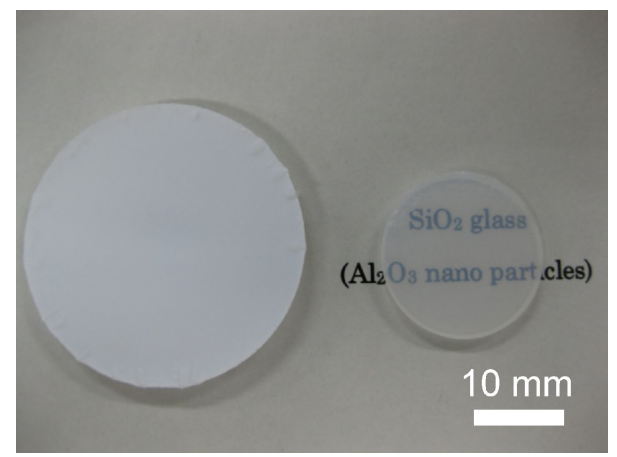

Fig. 2. Photographic images of the $0.6 \mathrm{~mol} \% \mathrm{Al}_{2} \mathrm{O}_{3}$ doped $\mathrm{SiO}_{2}-\mathrm{PVA}$ nanocomposite (left) and the $\mathrm{Al}_{2} \mathrm{O}_{3}$ doped silica glass obtained by sintering the nanocomposite at $1200^{\circ} \mathrm{C}$ for $6 \mathrm{~h}$ in air (right).

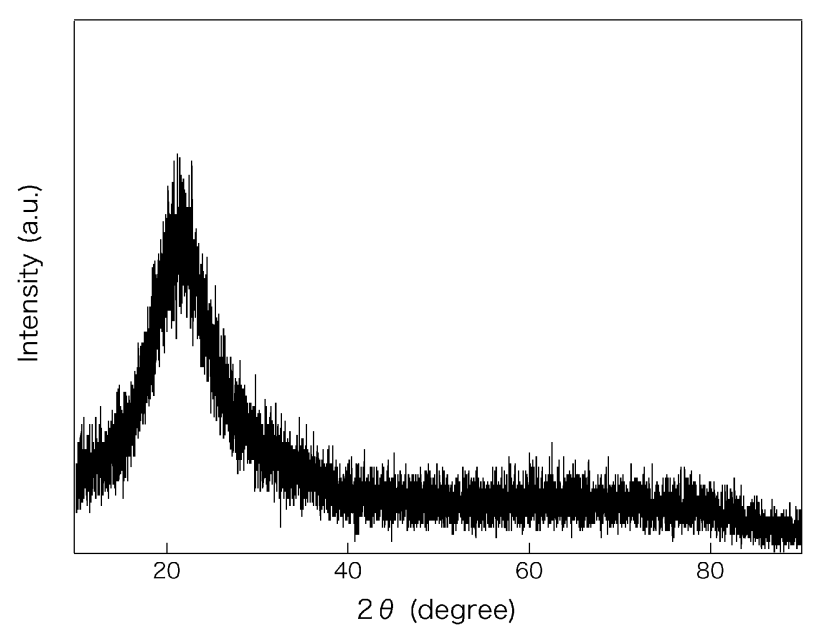

Fig. 3. XRD pattern of the $0.6 \mathrm{~mol} \% \mathrm{Al}_{2} \mathrm{O}_{3}$-doped silica glass obtained by sintering the nanocomposite at $1200^{\circ} \mathrm{C}$ for $6 \mathrm{~h}$ in air.

at $1100^{\circ} \mathrm{C}$ for $3-18 \mathrm{~h}$. In contrast, complete densification of the $0.6 \mathrm{~mol} \% \mathrm{Al}_{2} \mathrm{O}_{3}$ doped nanocomposite was not achieved at $1100^{\circ} \mathrm{C}$ even after more than $18 \mathrm{~h}$, while transparent glass was obtained after sintering at $1200^{\circ} \mathrm{C}$ for $6-9 \mathrm{~h}$. At $1300^{\circ} \mathrm{C}$, a cristbalite phase was precipitated in the sintered body. In the case of the nanocomposite containing $1.2 \mathrm{~mol} \% \quad \mathrm{Al}_{2} \mathrm{O}_{3}$, however, transparent glass did not result from any of the heat-treatment temperatures over the range of $1100-1300^{\circ} \mathrm{C}$. With nanocomposites containing over $1.2 \mathrm{~mol} \% \quad \mathrm{Al}_{2} \mathrm{O}_{3}$ (results not shown), sintering of the nanocomposite was not accomplished by heattreatment within the range of $1100-1300^{\circ} \mathrm{C}$. These results indicate that the required sintering temperature of the nanocomposites increases with the concentration of the $\mathrm{Al}_{2} \mathrm{O}_{3}$ nanoparticles. Thus, transparent and monolithic silica glass doped with $\mathrm{Al}_{2} \mathrm{O}_{3}$ can be fabricated over the limited $\mathrm{Al}_{2} \mathrm{O}_{3}$ content range of $0-0.6 \mathrm{~mol} \%$. The optimal sintering conditions for the $0.6 \mathrm{~mol} \% \mathrm{Al}_{2} \mathrm{O}_{3}$ doped nanocomposite were determined to be $1200^{\circ} \mathrm{C}$ for $6 \mathrm{~h}$ in air. Figure 2 presents photographic images of the $0.6 \mathrm{~mol} \% \mathrm{Al}_{2} \mathrm{O}_{3}$ doped $\mathrm{SiO}_{2}$-PVA nanocomposite and the resulting sintered silica glass. Subsequent to these trials, detailed evaluations of the 0.6 mol \% $\mathrm{Al}_{2} \mathrm{O}_{3}$-doped silica glass were carried out.

Figure 3 shows the XRD pattern of the $0.6 \mathrm{~mol} \% \mathrm{Al}_{2} \mathrm{O}_{3}$ doped silica glass. The diffraction pattern is broad due to the silica glass matrix and does not exhibit any characteristic peaks of crystalline $\mathrm{Al}_{2} \mathrm{O}_{3}$ because of the low $\mathrm{Al}_{2} \mathrm{O}_{3}$ concentration (0.6 

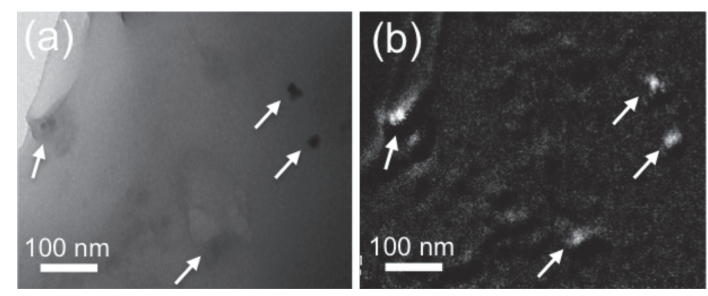

Fig. 4. (a) TEM image (bright field) and (b) EELS elemental mapping for aluminum in the $0.6 \mathrm{~mol} \% \mathrm{Al}_{2} \mathrm{O}_{3}$ doped silica glass obtained by sintering the nanocomposite at $1200^{\circ} \mathrm{C}$ for $6 \mathrm{~h}$ in air. The arrows indicate $\mathrm{Al}_{2} \mathrm{O}_{3}$ nanoparticles.

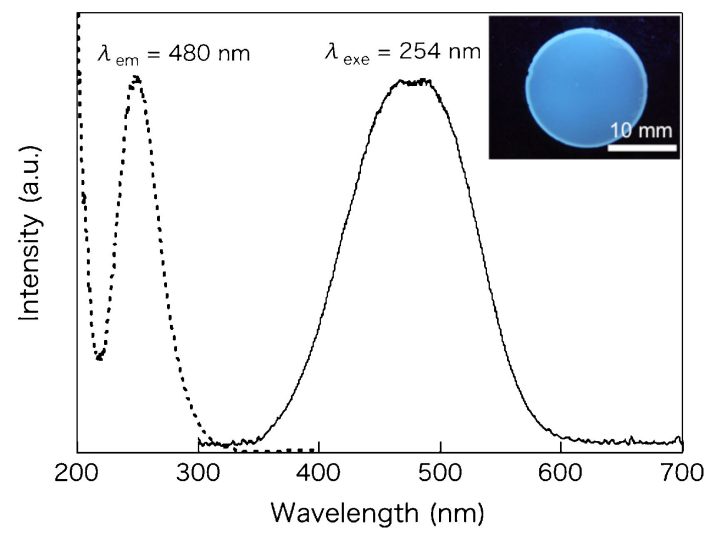

Fig. 5. PLE (broken line) and PL (solid line) spectra of the $0.6 \mathrm{~mol} \%$ $\mathrm{Al}_{2} \mathrm{O}_{3}$ doped silica glass obtained by sintering the nanocomposite at $1200^{\circ} \mathrm{C}$ for $6 \mathrm{~h}$ in air. Inset photograph shows the glass sample under a UV lamp at a wavelength of $254 \mathrm{~nm}$.

mol\%). To confirm the $\mathrm{Al}_{2} \mathrm{O}_{3}$ in the sintered silica glass, the morphology of the $\mathrm{Al}_{2} \mathrm{O}_{3}$ doped silica glass was observed by means of TEM and EELS, as shown in Fig. 4. In the TEM image, particles $10-30 \mathrm{~nm}$ in size can be observed in the glass matrix. These nanoparticle sizes are comparable to those of the initial fumed alumina (mean diameter of $13 \mathrm{~nm}$ ). In addition, the EELS elemental mapping for Al shows that these nanoparticles contained $\mathrm{Al}$ ions. Based on the results of previous study on the preparation of crystalline $\mathrm{Al}_{2} \mathrm{O}_{3}$-doped silica glasses, ${ }^{3)} \alpha$-alumina may be present in the sintered glass. In fact, XRD data from the present study indicated that fumed alumina heat-treated at $1200^{\circ} \mathrm{C}$ consisted $\alpha$-alumina (data not shown). These results suggest that crystalline $\mathrm{Al}_{2} \mathrm{O}_{3}$ nanoparticles were dispersed in the silica glass matrix even after sintering at $1200^{\circ} \mathrm{C}$.

The dispersion state of the $\mathrm{Al}_{2} \mathrm{O}_{3}$ nanoparticles in the silica matrix was further confirmed by measurement of the Vickers hardness of the glass. It has been reported that crystal particles dispersed in a glass matrix improve the fracture toughness of the glass, because these particles suppress crack propagation. ${ }^{15)}$ Therefore, it was anticipated that the mechanical strength of the sintered glass would be improved by the $\mathrm{Al}_{2} \mathrm{O}_{3}$ nanoparticles, assuming homogeneous dispersion in the silica matrix. In fact, the Vickers hardness (Hv) value of the glass was found to be 797, which was slightly higher than that of the non-doped silica glass $(\mathrm{Hv}=777)$. This increase in the hardness of the glass indicates that the $\mathrm{Al}_{2} \mathrm{O}_{3}$ nanoparticles were dispersed throughout the whole silica glass matrix

The $\mathrm{Al}_{2} \mathrm{O}_{3}$ nanoparticle doped silica glass demonstrated PL characteristics under UV irradiation, and Fig. 5 presents the photoluminescence excitation (PLE) and PL spectra of the glass.

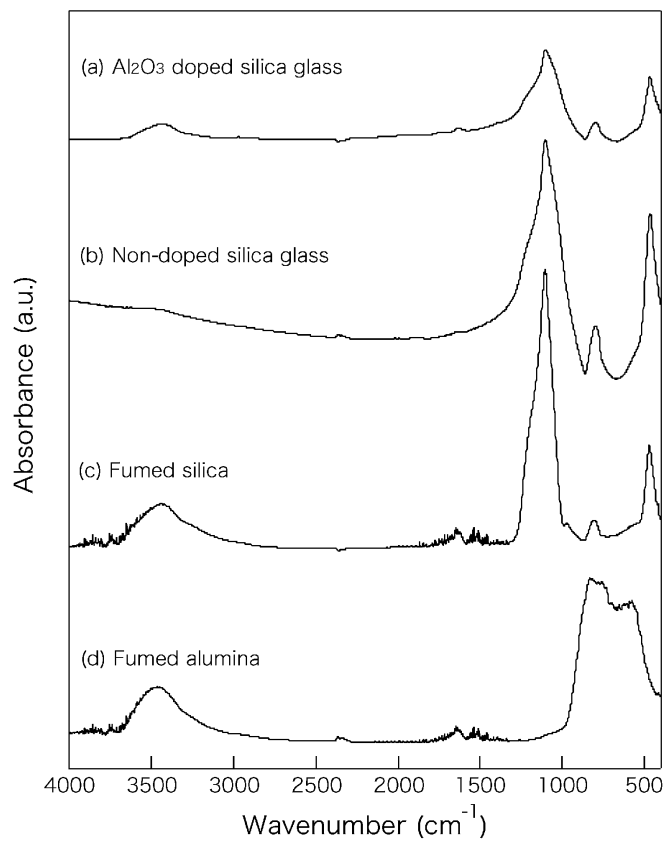

Fig. 6. FT-IR spectra of (a) $0.6 \mathrm{~mol} \% \mathrm{Al}_{2} \mathrm{O}_{3}$ doped silica glass sintered at $1200^{\circ} \mathrm{C}$ for $6 \mathrm{~h}$ in air, (b) non-doped silica glass sintered at $1100^{\circ} \mathrm{C}$ for $3 \mathrm{~h}$ in air, (c) as-received fumed silica and (d) as-received fumed alumina.

Blue PL was observed upon UV excitation, as shown in the inset photograph, and is attributed to the broad emission band located at approximately $480 \mathrm{~nm}$. In the excitation spectrum, a broad band is located in the vicinity of $250 \mathrm{~nm}$. In contrast, sintered silica glass without $\mathrm{Al}_{2} \mathrm{O}_{3}$ nanoparticles showed no PL during UV excitation (data not shown). These results indicate that the addition of $\mathrm{Al}_{2} \mathrm{O}_{3}$ nanoparticles to the silica glass resulted in the PL characteristics of the sintered glass.

\section{Discussion}

The effect of $\mathrm{Al}_{2} \mathrm{O}_{3}$ nanoparticles on the sintering conditions of the $\mathrm{SiO}_{2}$-PVA nanocomposite and the $\mathrm{PL}$ characteristics of the sintered glass is discussed in terms of the morphology and structure of the doped glass. The addition of $\mathrm{Al}_{2} \mathrm{O}_{3}$ nanoparticles resulted in an increment in the sintering temperature. According to a previous study on the sintering of amorphous $\mathrm{SiO}_{2}$ particles, ${ }^{16)}$ sintering occurs due to the viscous flow of these particles at high temperatures. Thus, the sintering behavior of $\mathrm{SiO}_{2}$ is related to its viscosity at a given temperature. In the case of sintering of an $\mathrm{SiO}_{2}-\mathrm{Al}_{2} \mathrm{O}_{3}$ composite $\left(\mathrm{Si}: \mathrm{Al}=1: 3.68\right.$, molar ratio), ${ }^{17)}$ the viscosity of the $\mathrm{SiO}_{2}$ at $1000^{\circ} \mathrm{C}$ was found to increase by the addition of $\mathrm{Al}_{2} \mathrm{O}_{3}$, since the viscous flow of $\mathrm{Al}_{2} \mathrm{O}_{3}$ particles does not proceed at this temperature. In the present study, therefore, it is presumed that the rigid $\mathrm{Al}_{2} \mathrm{O}_{3}$ nanoparticles inhibited sintering of the $\mathrm{SiO}_{2}$ nanoparticles by increasing the viscosity of the nanocomposite at the heat treatment temperature. Consequently, the sintering temperature of the nanocomposite increased by the addition of $\mathrm{Al}_{2} \mathrm{O}_{3}$ nanoparticles.

The addition of $\mathrm{Al}_{2} \mathrm{O}_{3}$ nanoparticles also caused the sintered silica glass to exhibit PL. According to prior work concerning the PL characteristics of $\mathrm{Al}_{2} \mathrm{O}_{3}$ doped silica glass, ${ }^{3)} \mathrm{OH}$ groups present on $\mathrm{Al}_{2} \mathrm{O}_{3}$ and $\mathrm{SiO}_{2}$ contribute to the $\mathrm{PL}$ emission of the material. To elucidate the effect of $\mathrm{OH}$ groups in sintered glass on the PL characteristics, the structure of the $\mathrm{Al}_{2} \mathrm{O}_{3}$ doped silica glass was evaluated by means of FT-IR measurements. Figure 6 shows the FT-IR spectra of $\mathrm{Al}_{2} \mathrm{O}_{3}$ doped silica glass, non-doped 
silica glass, fumed silica and fumed alumina. In the spectra of the fumed silica and fumed alumina, broad absorption peaks are observed at approximately $3450 \mathrm{~cm}^{-1}$, attributed to the stretching vibrations of $\mathrm{Si}-\mathrm{OH}^{18)}$ and $\mathrm{Al}-\mathrm{OH}$ groups. ${ }^{19), 20)}$ It has been previously reported in the literature ${ }^{21)}$ that the surface $\mathrm{Si}-\mathrm{OH}$ density of fumed silica is approximately $2.5 \mathrm{Si}-\mathrm{OH} / \mathrm{nm}^{2}$. In the spectrum of the non-doped sintered silica glass, the intensity of the $\mathrm{Si}-\mathrm{OH}$ peak is reduced compared to that in the fumed silica spectrum. The result suggests that the condensation reaction of the $\mathrm{Si}-\mathrm{OH}$ groups $\left(2 \mathrm{Si}-\mathrm{OH} \rightarrow \mathrm{Si}-\mathrm{O}-\mathrm{Si}+\mathrm{H}_{2} \mathrm{O}\right)$ progressed concomitantly with the sintering of the particles above $1000^{\circ} \mathrm{C}^{22)}$ The spectrum of $\mathrm{Al}_{2} \mathrm{O}_{3}$ doped silica glass, in contrast, shows that considerable $\mathrm{Si}-\mathrm{OH}$ or $\mathrm{Al}-\mathrm{OH}$ groups remained in the sintered glass even after sintering at $1200^{\circ} \mathrm{C}$ for $6 \mathrm{~h}$. Additionally, there is no discernible peak from the $\mathrm{Si}-\mathrm{O}-\mathrm{Al}$ stretching vibration in the region of $600-700 \mathrm{~cm}^{-1}$. ${ }^{23)}$ In the case of the $\mathrm{Al}_{2} \mathrm{O}_{3}$ nanoparticles doped silica glass, therefore, it is assumed that considerable $\mathrm{Al}-\mathrm{OH}$ and $\mathrm{Si}-\mathrm{OH}$ groups were present at the interfaces between the $\mathrm{Al}_{2} \mathrm{O}_{3}$ nanoparticles and silica glass matrix even after sintering.

The PL spectra of the as-received fumed alumina (the starting material) and fumed alumina heat-treated at $1200^{\circ} \mathrm{C}$ for $6 \mathrm{~h}$ in air were examined in order to confirm the effect of $\mathrm{Al}_{2} \mathrm{O}_{3}$ on the $\mathrm{PL}$ characteristics of the material. As a result, no characteristic emission band was observed in the spectra of either of these fumed alumina samples. In addition, the PL spectra of the asreceived fumed silica (the starting material) and heat-treated fumed silica also did not exhibit characteristic emission bands. Therefore, it is assumed that the blue PL is due to the presence of defects related to the $\mathrm{Al}-\mathrm{OH}$ and $\mathrm{Si}-\mathrm{OH}$ groups at the interfaces between $\mathrm{Al}_{2} \mathrm{O}_{3}$ nanoparticles and the silica glass matrix, although the mechanism by which the PL arises has not yet been determined. More detailed investigations of the interfaces between the $\mathrm{Al}_{2} \mathrm{O}_{3}$ nanoparticles and the silica matrix should be further performed in future to determine the origin of the PL of the $\mathrm{Al}_{2} \mathrm{O}_{3}$ nanoparticle doped silica glass.

\section{Conclusions}

The $0.6 \mathrm{~mol} \% \quad \mathrm{Al}_{2} \mathrm{O}_{3}$ nanoparticle-doped nanocomposite was found to require sintering at $1200^{\circ} \mathrm{C}$. TEM, EELS, and Vickers hardness analyses showed that the $\mathrm{Al}_{2} \mathrm{O}_{3}$ nanoparticles were dispersed in the silica matrix. It is considered that the $\mathrm{Al}_{2} \mathrm{O}_{3}$ nanoparticles inhibited the sintering of the $\mathrm{SiO}_{2}$ nanoparticles, resulting in an increase in the required sintering temperature. The resulting material exhibited broad PL emission around $480 \mathrm{~nm}$ under UV excitation, presumably because of defects involving $\mathrm{Si}-\mathrm{OH}$ or $\mathrm{Al}-\mathrm{OH}$ groups. The method presented herein is con- sidered to be an attractive technique for the fabrication of nanoparticle doped silica glass.

Acknowledgment This work was supported by a JSPS KAKENHI Grant Number 26420756. S. Fujino acknowledges the Asahi Glass foundation.

\section{References}

1) T. Hayakawa, T. Enomoto and M. Nogami, J. Mater. Res., 17, 1305-1311 (2002).

2) A. Amlouk, L. El Mir, S. Kraiem and S. Alaya, J. Phys. Chem. Solids, 67, 1464-1468 (2006).

3) L. El Mir, A. Amlouk and C. Barthou, J. Phys. Chem. Solids, 67, 2395-2399 (2006).

4) L. El Mir, A. Amlouk, C. Barthou and S. Alaya, Mater. Sci. Eng., C, 28, 771-776 (2008).

5) F. Kirkbir, H. Murata, D. Meyers, S. R. Chaudhuri and A. Sarkar, J. Sol-Gel Sci. Technol., 6, 203-217 (1996).

6) E. M. Rabinovich, J. B. Macchesney, D. W. Johnson, J. R. Simpson, B. W. Meagher, F. V. Dimarcello, D. L. Wood and E. A. Sigety, J. Non-Cryst. Solids, 63, 155-161 (1984).

7) R. Clasen, J. Non-Cryst. Solids, 89, 335-344 (1987).

8) M. Toki, S. Miyashita, T. Takeuchi, S. Kanbe and A. Kochi, J. Non-Cryst. Solids, 100, 479-482 (1988).

9) R. D. Shoup, Ceramic Bulletin, 70, 1505-1510 (1991).

10) L. Costa and D. Kerner, J. Sol-Gel Sci. Technol., 26, 63-66 (2003).

11) H. Ikeda, S. Fujino and T. Kajiwara, J. Ceram. Soc. Japan, 119, 65-69 (2011).

12) H. Ikeda and S. Fujino, J. Porous Mater, 21, 1143-1149 (2014).

13) H. Ikeda, S. Fujino and T. Kajiwara, J. Ceram. Soc. Japan, 120, 238-242 (2012).

14) H. Ikeda, T. Murata and S. Fujino, Opt. Mater., 36, 1119-1122 (2014).

15) P. F. James, J. Non-Cryst. Solids, 181, 1-15 (1995).

16) E. M. Rabinovich, J. Mater. Sci., 20, 4259-4297 (1985).

17) R. Saliger, T. Heinrich, T. Gleissner and J. Fricke, J. NonCryst. Solids, 186, 113-117 (1995).

18) K. M. Davis and M. Tomozawa, J. Non-Cryst. Solids, 185, 203-220 (1995).

19) L. Kubelkova, J. Novakova and K. Nedomova, J. Catal., 124, 441-450 (1990).

20) K. Gora-Marek and J. Datka, Appl. Catal., A, 302, 104-109 (2006).

21) J. Mathias and G. Wannemacher, J. Colloid Interface Sci., 125, 61-68 (1988).

22) T. Yamada, M. Nakajima, T. Suemoto and T. Uchino, J. Phys. Chem. C, 111, 12973-12979 (2007).

23) M. Okuno, N. Zotov, M. Schmucker and H. Schneider, J. NonCryst. Solids, 351, 1032-1038 (2005). 